an attempt at first legislation? Is it not merely an attempt to patch up old and inoperative laws by employing the same defective local machinery as they constituted? $\mathrm{He}$ is incorrect in suggesting that we object to this measure because it is not perfect. We ask only that the next step, however elementary, may be safe. We as little expect "perfection," and probably are as much guided by commonsense in this respect, as "M.D. Lond." himself. But we show how the Bill may be amended, so as to aroid the defects of previous legislation, without enacting, as this measure would enact, fresh and perhaps insurmountable obstacles to a more complete organisation in future. And we ask our brethren in the metropolis not to empley that influence which their nearer proximity to the centre of administration may give them, to establish more firmly local obstructions to sound sanitary progress. We desire only a fair statement of facts and fair reasoning therefrom, and we do not fear the result.-I am, Sir, \&c.,

$$
\text { Cheltenham, June 12, } 1872 . \quad \text { H. W. RUMSEX. }
$$

** Dr. Rumsey is particularly unfortunate in selecting the metropolis as an illustration of the unity which would exist between county boards and boards of guardians. The Metropolitan Board of Works, although elected by the vestries, has nothing in common with them; indeed, they are in frequent opposition. The officers of the local authorities are not in any way subject to the Board of Works, and the vestries would most strenuously resist any attempt to make the Board of Works an authority to whom appeal would lie. Far from county boards acting in concert with boards of guardians, the whole of Dr. Rumsey's argument goes to show that the former would be useful chiefly in controlling them, or, in other words, in making the latter act when they were unwilling to do so. Such a state of things would be most objectionable. As to county boards acting as courts of appeal in respect to medical relief, the thing is simply impossible. The medical officers are the servants of the guardians, their appointments are made under the sanction of the Local Government Board, and half their salaries are paid from the Consolidated Fund. This arrangement could not be altered without disturbing a number of existing Acts of Parliament; and even if Dr. Rumsey's proposal were carried out, there is no guarantee that the county board would improve the pay and status of the Poorlaw medical officers. Certainly, the appointment of a highly paid expert to relieve them of some of their most important duties would not be the way to do so. We must protest against the idea that we are representing the interests or views of the metropolitans, many of whom hold views in opposition to our own. We have endeavoured to consider the general interests of the profession and the public, and although Mr. Stansfeld's Bill is not by any means all we could desire, we believe that it constitutes an advance in the right direction, and we sincerely hope that it will not be delayed or postponed for the introduction of county boards.-Ev. L.

\section{THE TANNER MEMORIAL FUND.}

\section{To the Editor of THE LANCET.}

SrR,-Dr. Percy Boulton, treasurer to the fund raised for the purpose of establishing a memorial to the late Dr. Thomas Hawkes Tanner, has requested me to announce to the subscribers that the amount collected has been forwarded to the Council of King's College, and the interest (£10) per annum will form an annual prize in the class of Obstetric Medicine, which will be called the "Tanner Prize."

The Council and Medical Board of King's College kave each much pleasure in thus establishing a prize which will perpetuate the memory of a distinguished student in the college in which he was educated.

$$
\text { I remain, yours most faithfully, }
$$

\section{detledical alletos.}

Royal College of Surgeons of Fingland The following gentlemen, having passed the required examination, received their diplomas in Dental Surgery at a meeting of the Board of Examiners on Tuesday last:-

Baylis, Leighton, Cheltenham.

Coles, James Oakley, Wımpo'e-street.

Harding, William Edward, Stafford.

Hutchinson, Samuel John, Manche
Poundall, William Lioyd, Derby.

The dental examination at the College is now divided into two parts, the first day being devoted to written papers, and the last day to vivâ-voce and practical examination.

A potheraries' Hall. - The following gentlemen passed their examination in the Science and Practice of Mediaine, and received certificates to practise, on the 20 th inst.:Cartwright, John Peploe, Oswestry.

Dove, Henry, Norwich.

Laver, Arthur Henry, Raleigh, Essex.

dise, Thomas Decimus, Stamford, Lincolnshire.

As Assistants in Compounding and Dispensing Medicines :Jones, Owen, Long-acre.

Badcoek, Daniel, Barnard Castle.

On the same day the following gentlemen passed their First Professional Examination :-

Reginald Henry Foster, Guy's Hospital ; Samuel J. J. Kirby, Middlesex Hospital ; Alfred Charles Perrin, St. Thomas's Hospital.

Quenn's University in Ireland. - The following degrees were conferred by the Vice-Chancellor on the $19 \mathrm{th}$ of June :-

Docror IN MEDicine.-John George Adamson, Arehibald Adams, James 3. Bailey, Robert Evans Burges, Richard Davis, John G. Collis, Henry A. Fogerty, James Graham, John Hegarty, Wm. Hickman, H. Maturin Johnston, Francis B. Kane, John R. Leech, Samuel M'Cutcheon, Denis Peter Macdonald, Peter J. II Quaid, Hewry Madders, J. A. Malcomson, Timothy Moloney, W. E. Bonsall Moyn on, Bartholom: w O'Brien, Patrick Richard Read, James Ring, J. Nashville Rydm, J. M. J. Scott, Thomas Fraucis Sparrow, William F. Spencer, William Thompson, Hugh Charles Wilson.

MASTER IN SURGRBX.-Archibald Adams, John George Adamson, Moses Alack, Robert Erans Burges, Richard Davis, Willi:m Fieming, Henry A. Fogerty, James Graham, John Hegarty, Willam Hickman, Francis
B. Kane, John Leech, Peter J. M'Quaid, 'Timotby Moloney, Bartholomew O'Brien, Patrick O'Connell, 'Thomas Patterson, Richard Read, J. Ring, J. Scott, Wm. F. Spencer.

UNIVERSTTY of DUblin.--The following degrees were lately conferred :-

Bacheror of Medictn f. - James Henry Allen, Robert Archer, Charles B. Ball, John Chartres, Thos. P. Fleetwood, John C. Fullerton, George Goode, Alfied Grandison. Wm. L. Gubbins, James Charles Hamilton, Wm. F. Hingston, Elias Wm. Kerr, Wm. Lewis Mack y, Chas. Marsden, Frederick M'Loughlin, Chas. Alex, M'Mun, Mathew Denis Moriarty, Thomas P. O'Meara, Frederick Pope, William Josiah Smyly, Tnomas P. Thomas P. O'Meara, Freder

Master IN SurgerY.-Robert Archer, Charles B. Ball, Wm. F. Hingston, Frederick M'Loughlin.

Dr. Porter Smíth, of Shepton Mallet, bas been elected an Honorary Fellow of King's College, London.

A GenTLEMan writes to us making an offer to give $\$ 50$ to "the party who can find out a cure for hydrophobia."

Obstetrical Society of London.-At the next meeting of the Society, on Wednesday next, Dr. Aveling will read a paper on "Post-mortem Parturition"; after which other subjects will be introduced, amongst them that of "Irregular Uterine Contractions," which will be brought forward by Professor 'Trenholme, of Montreal.

Insurance Medical Fees. - In regard to the question of insurance fees we may state that the Crown Life Assurance Company pays a fee of one guinea in each case, irrespective of amount. Last year the medical fees paid were 2743 14s., exclusive of the salaries paid to the company's London medical officers. From the fortyseventh annual meeting, held on the 14th instant, we further learn that a dividend of $32 \mathrm{~s}$. per share was declared; and it was reported that of 778 policies for the sum of $\$ 389,445$ bad been issued during the present year, yielding 212,537 of annual premiums; that the net funds were $21,205,414$; the insurances in force, $24,762,106$; the annual increase, $£ 188,633$; that the total claims paid now amounted to $£ 2,269,000$. 